\title{
In Vitro Evaluation Of Naproxen Metabolite, O-Desmethylnaproxen On A Mouse Connective Tissue Fibroblast Cells
}

\section{Fare Bağ Dokusu Fibroblast Hücreleri Üzerinde Naproksen metaboliti O-Desmetilnaproksenin In Vitro Değerlendirilmesi}

\author{
Esin Akbay ${ }^{1 \oplus}$, Yusuf Doruk Aracagök ${ }^{1 \oplus}$, Hakan Göker $^{2}{ }^{\odot}$, Mehmet Ali Onur $^{1 \oplus}$, Nilüfer Cihangir ${ }^{1 \odot}$ \\ ${ }^{1}$ Department of Biology, Hacettepe University, Ankara, Turkey. \\ ${ }^{2}$ Central Instrumental Analysis II Laboratory, Ankara University, Ankara, Turkey.
}

\section{ABSTRACT}

\begin{abstract}
The aim of this in vitro study was assessment of the cytotoxic level of $O$-desmethylnaproxen. A mouse connective tissue fibroblast cell line, L929 was exposed to naproxen and O-desmethylnaproxen in different concentrations for 24- and 48- hours. Cell viability was tested by 3-[4,5-dimethylthiazol-2-yl]-2,5-diphnyltetrazolium bromide (MTT), while apoptosis was determined by acridine orange/propidium iodide (AO/PI) double staining method. The control group was free from any agent (Dulbecco's Modified Eagle's Medium (DMEM) only) and accepted as 100\% cell viability. The IC50 results indicated that the inhibition of $50 \%$ cell viability was resulted by the highest concentration of O-desmethylnaproxen $(0.7 \mu \mathrm{g} / \mathrm{mL})$ while none of naproxen concentration was caused $50 \%$ cell death. Consequently, to avoid the unacceptable side effects of naproxen metabolites that evacuated by urine; further studies should be conducted to determine the accumulation of naproxen metabolites.
\end{abstract}

\section{Key Words}

Cytotoxicity, naproxen, $O$-desmethylnaproxen, in vitro.

\section{öz}

u in vitro çalışmanın amacı, O-desmetilnaproksen’nin sitotoksik seviyesinin belirlenmesidir. Bu amaçla, L929 hücre hattı, fare bağ doku fibroblast hücreleri, 24-ve 48-saat boyunca farklı konsantrasyonlarda naproksen ve O-desmetilnaproksene maruz bırakılmıştır. Hücre canlılığı MTT ile test edilirken, apoptoz AO/PI çift boyama yöntemi ile belirlenmiştir. Kontrol grubu herhangi bir ajan içermeyen (sadece DMEM) ve \% 100 hücre canlılığı olan grup olarak kabul edilmiştir. IC50 sonuçları, \% 50 hücre ölümüne neden olan grubun en yüksek konsantrasyona sahip 0-desmetilnaproksen'de (0.7 ug / mL) ortaya çıktı̆̆ı ancak naproksen konsantrasyonlarının, \% 50 hücre ölümüne neden olmadığı tespit edilmiştir. Sonuç olarak, idrarla vücuttan uzaklaştırılan naproksen metabolitlerinin, dikkate alınmayan yan etkilerinden kaçınmak için; naproksen metabolitlerinin birikimini belirlemek amacı ile daha ileri çalışmalar yapılmalıdır.

\section{Anahtar Kelimeler}

Anahtar Kelimeler: Sitotoksisite, naproksen, $\mathrm{O}$-desmetilnaproksen, in vitro.

Article History: Received: Feb 20, 2020; Revised: Oct 04, 2020; Accepted: Oct 8, 2020; Available Online: Oct $30,2020$. DOI: https://doi.org/10.15671/hjbc.680564 


\section{INTRODUCTION}

buprofen, diclofenac, and naproxen (non-steroidal anti-inflammatory drugs: NSAIDs) are used widely to reduce pain, fever, and inflammation. Naproxen ((S)-6-methoxy- $\alpha$-methyl-2-naphthaleneaceticacid), is an NSAID with analgesic and antipyretic properties [1] Naproxen was found to be rapidly absorbed in all species and, once in the blood, was eliminated with halflives ranging from 2 to 35 hours [2]. Naproxen is mainly metabolized in humans to form two major metabolites (naproxen acyl glucuronide and $\mathrm{O}$-desmethylnaproxen) It is released from the body in the unchanged form of conjugated with $\mathrm{O}$-desmethylnaproxen sulfate and glucuronic acid [3]. This drug can transform into O-desmetyhlnaproxen via cytochrome P450 enzymes (CYP2C9 and CYP1A2 enzymes) [4], which can also be done by fungal species. Fungal cytochrome enzymes play a key role on the transformation of pharmaceutical compounds. One study was reported that naproxen metabolism of Cunninghamella species shows some similarities with human naproxen metabolism. Also, in the same study, they reported that desmethylnaproxen and desmethylnaproxen-6-sulfate was transformed from naproxen by Cunninghamella species [5].

Naproxen and its metabolites were excreted via urine from the body [6]. After metabolized of naproxen, approximately $40 \%$ of its recovered from the urine as naproxen conjugate, $10 \%$ as glucuronide naproxen, $12 \%$ as the glucuronide conjugate desmethylnaproxen, 5\% as desmethylnaproxen and unknown conjugates of naproxen and desmethylnaproxen (app. 30\%) [7].

NSAIDs and their metabolites were also detected commonly in the aquatic environment [8]. It was detected in aquatic environments from $n g \mathrm{~L}-1$ to several $\mu \mathrm{g} L-1$, due to excessive use of naproxen [9]. Due to naproxen released about $30 \%$ as $O$-desmetyhlnaproxen with urine, it was detected in many environmental samples such as wastewater and surface water. Hühnerfuss et al. (2010) reported in their study that in two of the surface water samples taken from rivers, $\mathrm{O}$-desmetyhlnaproxen level was 1.34 and $1.36 \mu \mathrm{g} / \mathrm{L}$ at high concentrations. Therefore, determining the dose of $\mathrm{O}$-desmetyhlnaproxen toxicity is important for public health as well as life in the water [10].

As mentioned in many other studies, under in vitro conditions effects of compounds and their mechanism can be tested safe, and quickly in different cell lines. Cytotoxicity tests are the most common and easiest ways to measure the toxic effects of the chemicals [11]. In the literature, several markers have been defined to screen cytotoxicity of chemicals. Some researchers showed that in vitro studies results indicated that $O$-desmethylnaproxen, naproxen derivative, more toxic than its main compound on liver, lung, and intestinal cells, and at the same time it has eco-toxicity potential $[1,12-13]$.

The main aim of this study was to determine the dose depended cytotoxicity effects of naproxen and its metabolite, O-desmethylnaproxen, on the mammalian connective tissue fibroblast cell line, L929. By identifying the toxicity potential of naproxen and $O$-desmethylnaproxen, useful information can be obtained about risk assessment for the environment and human health. Another important point is that the stereoisomers of many pharmaceutical active compounds can trigger different biological effects. This study may be the first in vitro study of the dose-dependent effects of $\mathrm{O}$-desmethylnaproxen on the mouse connective tissue fibroblast cell line.

\section{MATERIAL AND METHODS}

\section{Chemical agents}

Naproxen sodium (CAS Number: 26159-34-2), penicillin-streptomycin (CAS Number: 3810-74-0), MTT (CAS Number: 298-93-1), AO solution (CAS Number: 65-61-2), PI solution (CAS Number: 25535-16-4), and Dimethyl sulfoxide (DMSO) (CAS Number: 67-68-5) were obtained from Sigma Chemical Co. DMEM/F12 (Cat Number: FG 0415) and fetal bovine serum (FBS) (Cat Number: S 0415) was obtained from Biochrom AG, Germany. All chemicals and solvents were obtained as cell culture grade.

\section{$\boldsymbol{O}$-desmethylnaproxen production and isolation}

As described before, in our group's previous study O-desmethylnaproxen was obtained by Aspergillus niger spore suspension and identified by proton nuclear magnetic resonance ( ${ }^{1} \mathrm{H}$ NMR) and carbon-13 nuclear magnetic resonance $\left({ }^{13} \mathrm{C} N M R\right)[14]$.

\section{Proteomic analysis}

As in our group's previous study, proteomic analysis of O-desmethylnaproxen was done with LC/MS method [14]. 


\section{Preparation of chemicals doses}

Naproxen and $O$-desmethylnaproxen were prepared in seven different concentrations $(0.7,0.5,0.25,0.125$, $0.0625,0.03125$, and $0.0156 \mu \mathrm{g} / \mathrm{mL}$ ). To obtain the studied concentrations, both chemicals were dissolved first in DMSO and then diluted with culture media. All doses were studied in six parallel. The final concentrations of the solvent (DMSO) did not exceed $0.1 \%$.

In this study, naproxen and its metabolite concentrations applied for cytotoxicity test were used before for a previous study with osteoblastoma cancer cell line [15].

\section{Cell line determination}

L929, (ATCC cell line, NCTC clone 929), a mouse connective tissue fibroblast cell line, was preferred to use in this in vitro experiment. Fibroblast cells were selected because they are the predominant tissue type in the body. These cells are widely used for multiple purposes including biocompatibility and cytotoxicity tests due to their unlimited life span and their ability to multiply rapidly with a doubling time of 24 hours [16, 17]. Moreover, these cells are recommended by many standard institutions.

\section{Cell culture}

Cells were inoculated in 96-well culture plates at a density of $2 \times 10^{4}$ cells/well for MTT test and in 24-well culture plates at a density of $5 \times 10^{4}$ cells/well for $\mathrm{AO} / \mathrm{PI}$ double staining. The groups are control (untreated group), solvent control (DMSO treatment only), naproxen treatment, and $O$-desmethylnaproxen treatment group. The untreated cells were considered as a control group. $0.1 \%$ DMSO treated cell groups were regarded as a solvent control group. After 24- and 48-h of incubation, cell viabilities were assessed by the MTT assay. The assay was repeated in three independent experiments (with six replicates in each experiment; n:6). The percentage of cell viability was calculated by the following equation: [(A570 treated cells / A570 control cells) $\times 100$ $\%]$. The concentration that leads to $50 \%$ inhibition of viability $\left(\mathrm{IC}_{50}\right)$ was also calculated by regression analysis (S probit analysis program) (percent survival versus log concentration).

\section{Assessment of cell viability}

The colorimetric assay method was used as a standardized procedure defining viability [18]. Cell viability measures the percentage of a cell that is viable. At the end of the desired time point, $200 \mu \mathrm{l}$ medium containing $10 \mu \mathrm{l}$ $0.5 \mathrm{mg} / \mathrm{mL}$ MTT was replaced with the culture medium and plates were incubated for four hours at $37^{\circ} \mathrm{C}$. The medium was then removed and $100 \mu$ of isopropanol was added to the wells to solve the formed formazan crystals. The absorbance value was measured by using a microplate reader ( $\mu$ QuantTM, BiotekW Instruments Inc, USA) at a wavelength of $570 \mathrm{~nm}$. The absorbance of the treated cells was compared with that of the control, and cells exposed only to the normal medium were considered $100 \%$ viable.

\section{Acridine Orange (AO)/Propidium lodide (PI) double staining method}

For the determination stage of apoptosis at each time point of MTT, AO/PI double staining was performed according to the method of Mohan et al. 2011 [19]. AO is a vital dye that stains live and dead cells, while PI stains only cells that have lost their membrane integrity. After removing the chemical solutions and culture medium, cells were washed twice with PBS. Then, all groups were stained with the equal volume combination of $A O$ and $\mathrm{PI}(1 / 1 \mathrm{w} / \mathrm{w})$ for 20 seconds and washed twice with PBS for removing dyes. Then the mounting medium (glycerol/PBS; $1: 1(v / v))$ was applied to the cells to be observed under inverted microscopy with FITC and Rhodamine filter (Olympus IX70, Japan).

Following $\mathrm{AO} / \mathrm{PI}$ staining, apoptotic and necrotic cells were counted according to the following criteria [20, 21]: uniform green nucleus with an organized structure, intact plasma membrane, and orange or green cytoplasm, viable cells (1); bright green areas of chromatin condensation in the nucleus, early apoptosis (2); dense orange areas of chromatin condensation, late apoptosis (3); and orange intact nucleus, necrosis (4).

\section{Data analysis}

Statistical significance was determined with the GraphPad Prism 5.00 program. One-way analyses of variance (ANOVA) with Tukey post hoc test or Student t-test were used to analyses data. Data were expressed as mean \pm standard error and it was considered significant when $p$ $<0.05$ and $p<0.01$.

$I C_{50}$ values were calculated using SPSS statistics 17.0 software (Statistical Package for the Social Sciences Inc, Chicago, IL, USA) probit analysis. 


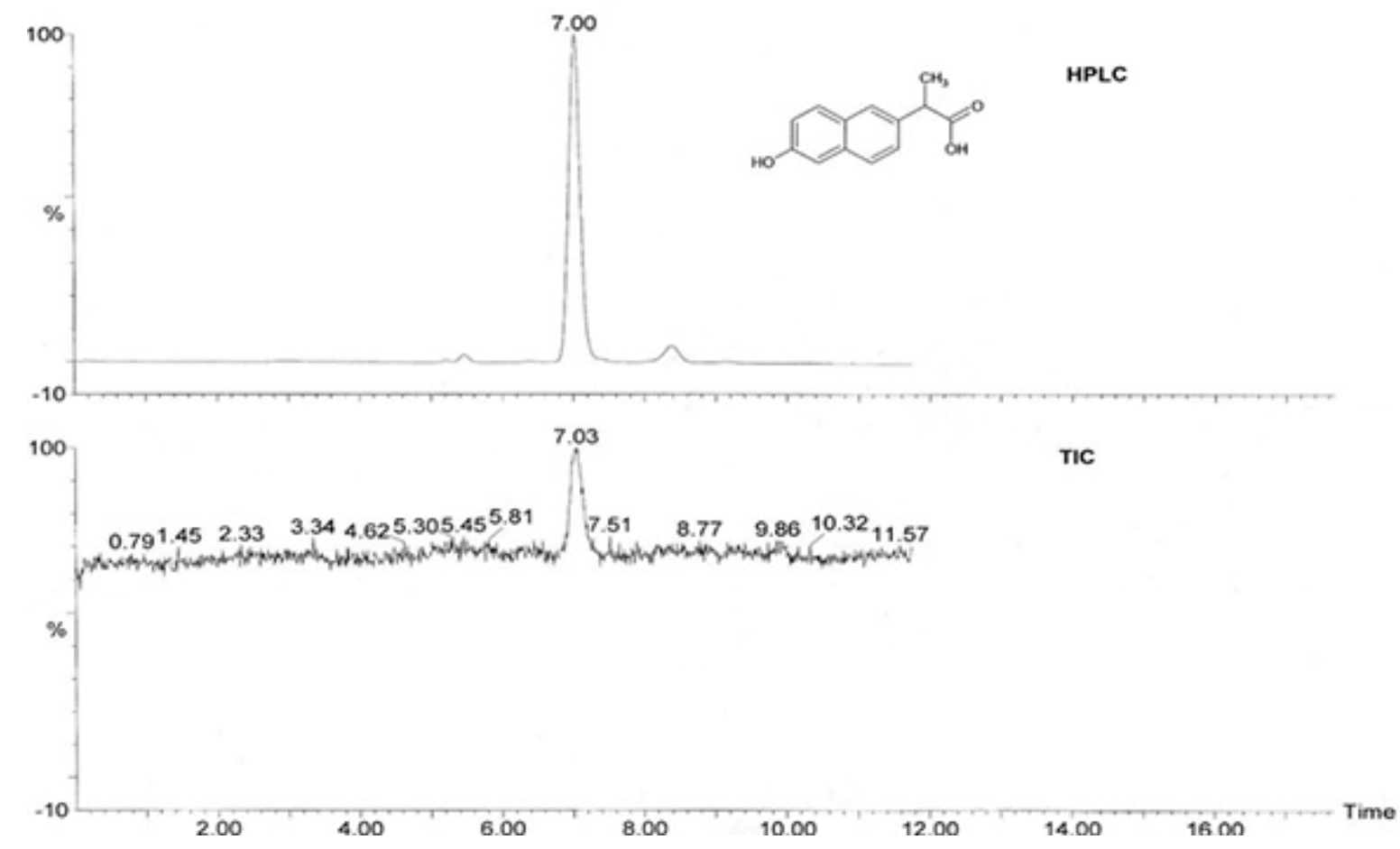

Figure 1.LC and total ion chromatogram of purified $O$-desmethylnaproxen.

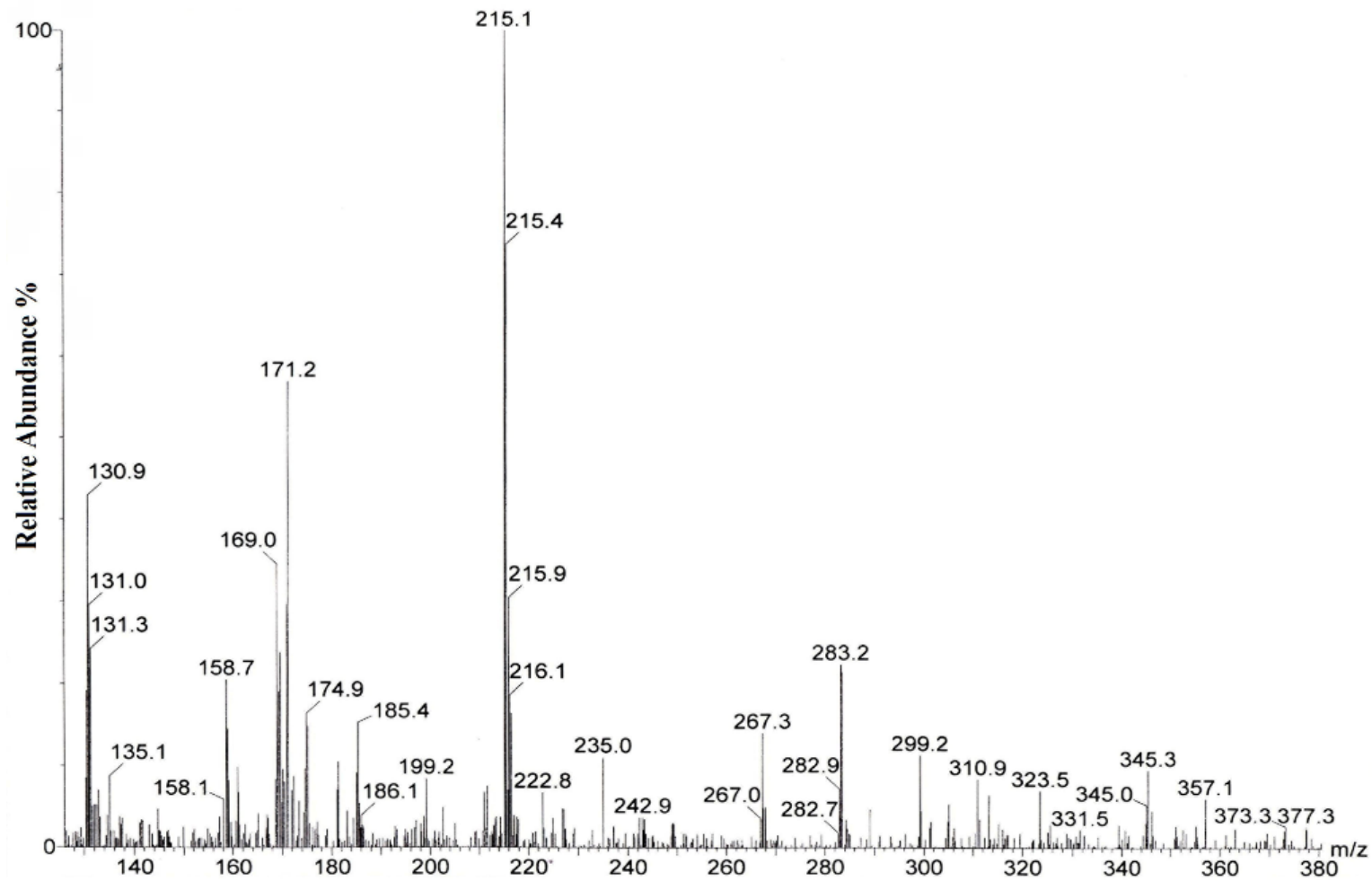

Figure 2.Full scan ESI (-) mass spectrum for $\boldsymbol{O}$-desmethylnaproxen. 


\section{RESULTS}

To determine the purity of $\mathrm{O}$-desmethylnaproxen, LC/ MS analysis was performed. According to LC/MS analysis, the purification of $O$-desmethylnaproxen (98\%) from culture media was obtained as shown in Figure 1.

As depicted in Figure 2, purified metabolite exhibits major ion at $\mathrm{m} / \mathrm{z} 215[\mathrm{M}-\mathrm{H}]$ which is 14 mass units lower than authentic naproxen $\left(\mathrm{C}_{14} \mathrm{H}_{14} \mathrm{O}_{3}\right)$. This result indicated that metabolite formed by loss of methyl group (O-desmethylnaproxen, $\mathrm{C}_{13} \mathrm{H}_{12} \mathrm{O}_{3}$ ). Besides LC/MS analysis we used ${ }^{1} \mathrm{HNMR}$, and ${ }^{13} \mathrm{CNMR}$ analysis in our former study to identify this metabolite [14].

$\mathrm{AO}$ and $\mathrm{PI}$ are intercalating nucleic acid-specific fluorochromes that revealed phases of morphological changes and the degree of induction of apoptosis. Fragmented DNA was observed in apoptosis as reddish orange color in naproxen metabolite treated group compared to untreated control cells with a green normal structure. Apoptotic cells were observed immediately after 24-h of treatment. As shown in Figure 5-b, the highest concentration of $\mathrm{O}$-desmethylnaproxen caused a critical decrease in proliferation and viability of cells. The number of apoptotic cell (yellow and orange) was more than the other concentrations of $\mathrm{O}$-desmethylnaproxen and control group. Despite this, no differences were observed between naproxen and the control group (Figure 6). In addition, these results were supported by cell count for apoptotic and necrotic cells. The quantitative results obtained from fluorescence images of L929 cells after $\mathrm{AO} / \mathrm{PI}$ dual staining are shown in Figure 7.

\section{DISCUSSION}

Naproxen is a member of the $\alpha$-aryl propionic acid group of NSAIDs and used worldwide for pain relief and in the treatment of osteo and rheumatoid arthritis [22].
The anti-inflammatory effects of NSAIDs results from inhibition of cyclooxygenase (COX) isoenzymes, which reduces the production of prostaglandins (lipid autacoids that play a role in various cellular processes such as angiogenesis, apoptosis and cell migration) [23]. In addition, in a previous study has reported that NSAIDs inhibit caspase catalytic activity and reduce the induction of cell death and inflammatory cytokines [24].

In human body naproxen transforms into sulphate metabolites, glycoconjugates and $\mathrm{O}$-desmethylnaproxen and conjugates. Naproxen and its metabolites were excreted via urine [6]. It is noted that some photoproducts of naproxen more toxic than mother compound [1]. The clearance of naproxen is $0.13 \mathrm{~mL} / \mathrm{min} / \mathrm{kg}$ according to product information; and approximately $95 \%$ of naproxen from any dose is excreted in the urine, primarily as the main compound $(<1 \%), 0$-desmethylnaproxen $(<1 \%)$ or their conjugates (66\% to $92 \%$ ).

When dealt with from another perspective as biological activity of pharmaceutically active compounds and their metabolites, in a previous report, it was notified that these compounds can enter aquatic environment in different ways such as excretion and disposal via wastewater [25]. Different pharmaceutical compounds were found in surface water, groundwater even in drinking water reservoirs [26]. Naproxen human metabolite O-desmethylnaproxen was found in 10 water samples from Germany and Pakistan [27]. For this reason, determining the toxicity of such compounds will lead to the obtaining of very useful information about drug metabolites and theirs negative effects.

It is well known that non-steroidal anti-inflammatory drugs (NSAIDs) reduce the growth of tumor network due to weakened local and systemic inflammation, possibly due to decreased prostaglandin production in tumor and host tissues. In the light of this information,

Table 1. The $I C_{50}$ values of two concentrations ( $\mathrm{d} 1$ and $\mathrm{d} 2$ ) of naproxen and O-desmethylnaproxen versus control on L929 cells; activity was evaluated by MTT assay after 48-h treatment with substances; data are expressed as the mean \pm SD of three independent experiments.

\begin{tabular}{cccc}
\hline Concentrations & Control & $\begin{array}{c}\text { Naproxen } \\
(\text { IC50 } \mu \mathrm{g} / \mathrm{ml})\end{array}$ & $\begin{array}{c}\text { O-desmethylnaproxen } \\
(\text { IC50 } \mu \mathrm{g} / \mathrm{ml})\end{array}$ \\
\hline $\mathrm{d} 1$ & 100 & $28.9 \pm 2.1$ & $46 \pm 5.1$ \\
\hline $\mathrm{d} 2$ & 100 & $16.7 \pm 1.2$ & $28.6 \pm 2.6$ \\
\hline
\end{tabular}




\section{MTT results- Naproxen}

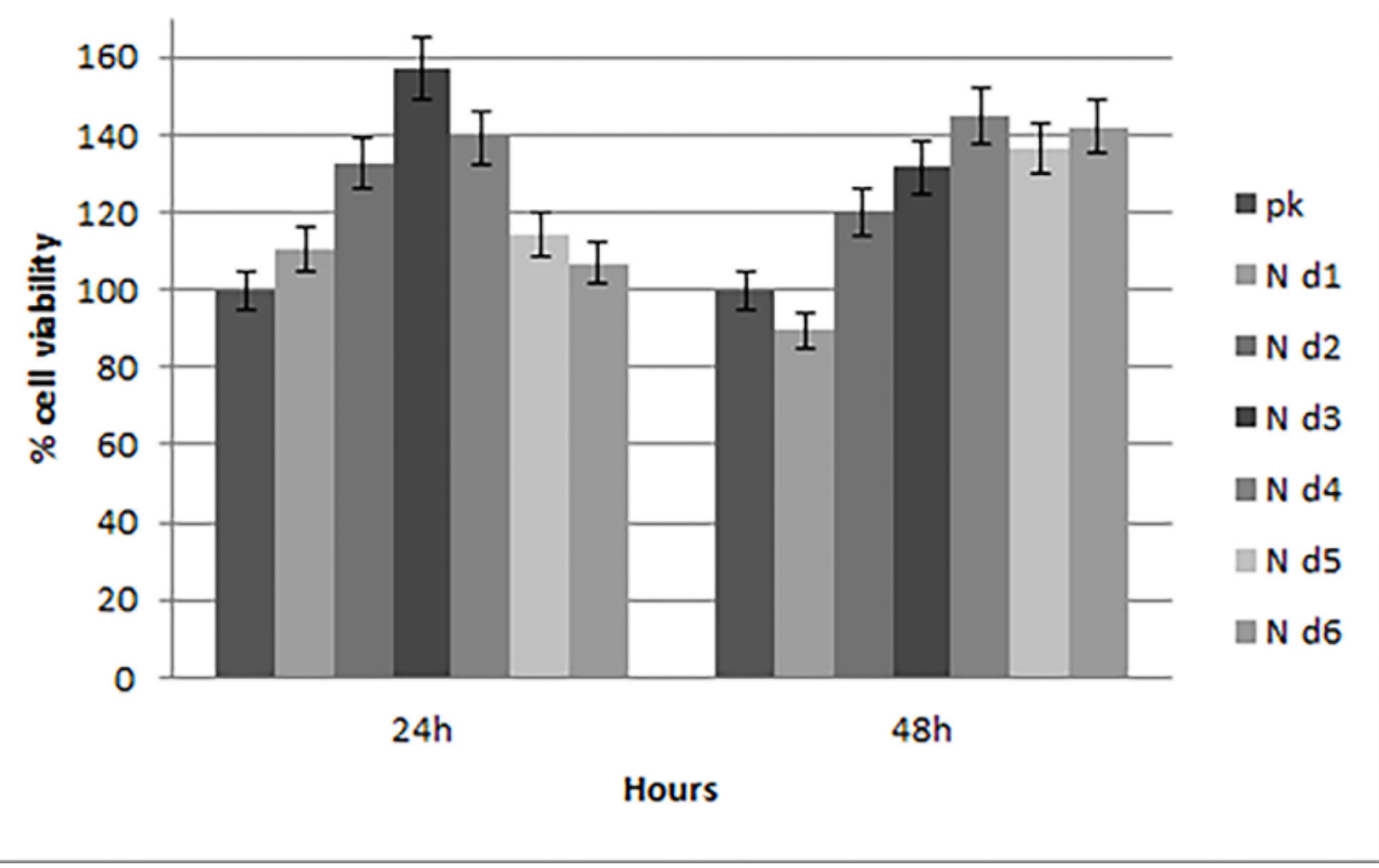

Figure 3. Results of MTT assay in $L 929$ cells treated with different doses of naproxen for 24 - and 48-h (d1: $0.7 \mu \mathrm{g} / \mathrm{ml}, \mathrm{d} 2: 0.5 \mu \mathrm{g} / \mathrm{ml}$, d3: $0.25 \mu \mathrm{g} / \mathrm{ml}, \mathrm{d} 4: 0.125 \mu \mathrm{g} / \mathrm{ml}, \mathrm{d} 5: 0.0625 \mu \mathrm{g} / \mathrm{ml}, \mathrm{d} 6: 0.03125 \mu \mathrm{g} / \mathrm{ml}, \mathrm{d} 7: 0.0156 \mu \mathrm{g} / \mathrm{ml})$. The results are represented as Means $\pm S D$ (n: 6). There were no differences between groups. (C: Control; SC: Solvent Control, N: Naproxen, d: dilution).

recent research has focused on the anti-proliferative effects of naproxen and its metabolites in many cancer cell types. In one of the recent reports published, it was reported that naproxen inhibited alkaline phosphatase activity in osteoblast cells with a certain dose and this inhibition might be an important finding in osteoblastoma mechanism [28]. They also reported the clinical benefits of NSAIDs in combination with chemotherapy in this report. In another study, the effects of naproxen on cancer cell line was worked and the report showed that this chemical agent inhibits cancer cell line's proliferation and directed the cells to apoptosis [29]. Also in another report, it was shown that high doses of NSAIDs have demonstrated antitumor activity in various cancer cell populations by inhibiting the proliferation of cancer cells and their migration potential [30]. There were numerous papers about therapeutic doses of naproxen. They reported that these kinds of drugs can also have various effects on somatic cells, inhibiting their diffe- rentiation potential and modulating their antigenic profile or some of their immune functions [29, 31-34]. These outputs have enhanced question about the cytotoxic effects of naproxen metabolites on somatic cells. In the present study, fibroblast cells were selected because they are the predominant tissue type in the body and in this study the cytotoxic effects of seven different doses of naproxen and its metabolite $O$-desmethylnaproxen were tested on a mouse connective tissue fibroblast cell line, L929. And we determined that $0.7 \mu \mathrm{g} / \mathrm{mL}$ of $O$-desmethylnaproxen inhibits cell growth by $50 \%$ after 48-h incubation. This result indicated that metabolite of naproxen may cause minor side effects before excreted from body. In lower doses of $\mathrm{O}$-desmethylnaproxen and all doses of naproxen, the toxicity is not noted in our study.

Aresta and his colleagues reported that naproxen is partly metabolized to $\mathrm{O}$-desmethylnaproxen, then both of them excreted in urine and while this happe- 


\section{MTT results- $O$-desmethylnaproxen}

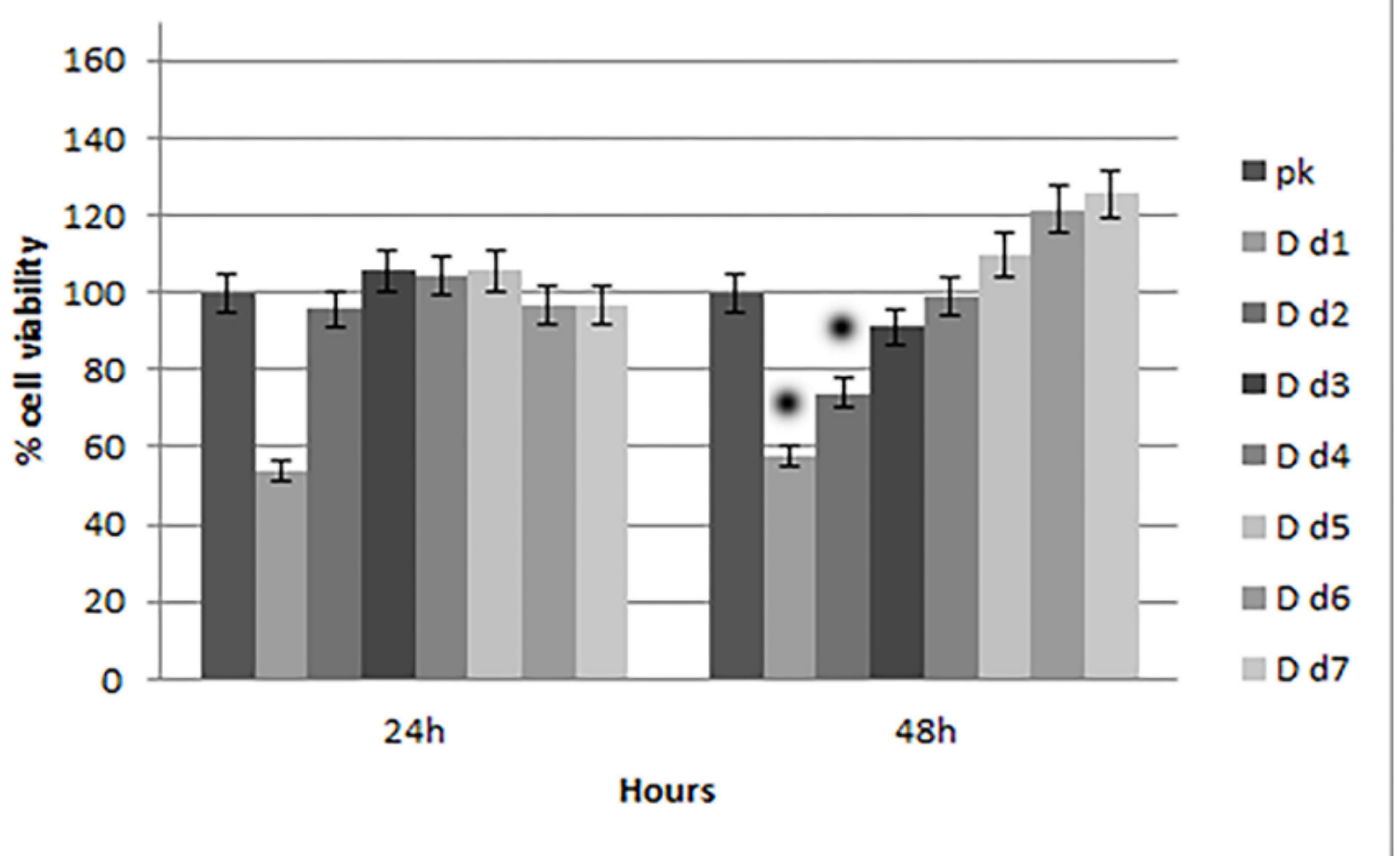

Figure 4. Results of MTT assay in L929 cells treated with different doses of O-desmethylnaproxen for 24- and 48-h (d1: 0.7 $\mu \mathrm{g} / \mathrm{ml}, \mathrm{d} 2$ : $0.5 \mu \mathrm{g} / \mathrm{ml}, \mathrm{d} 3: 0.25 \mu \mathrm{g} / \mathrm{ml}, \mathrm{d} 4: 0.125 \mu \mathrm{g} / \mathrm{ml}, \mathrm{d} 5: 0.0625 \mu \mathrm{g} / \mathrm{ml}, \mathrm{d} 6: 0.03125 \mu \mathrm{g} / \mathrm{ml}, \mathrm{d} 7: 0.0156 \mu \mathrm{g} / \mathrm{ml})$. The results are represented as Means $\pm S D(n: 6)$, letter "*" show significantly difference $(P<0.05)$ among groups of $O$-desmethylnaproxen $(D d 1$ and $D d 2)$ and control group. (C: Control; SC: Solvent Control, D: O-desmethylnaproxen, d: dilution).

ning, both of them associated with serious side effects such as ulcers in the stomach, kidney failure, and with a number of minor side effects [35]. In our study we also supported our results with further analysis in order to indicate the potential apoptotic induction of high dose $O$-desmethylnaproxen on connective tissue fibroblastic cells that include in a large amount in human body. Our results showed that death cell potential is decreasing in fewer doses and compare to control group highest dose of $O$-desmethylnaproxen induce cell to apoptosis $(p<0.05)$.

The importance of this study is that it was conducted as a preliminary study with quantitative data obtained in vitro before clinical studies. In the same way, it is also important in terms of providing a basis for the studies for clinical trials.
The main limitation of this study is that in this study one type of cell line was tested which is a standard used as a reliable mammalian cell line, L929, for cytotoxicity tests. Despite the fact that cell-culture studies are very widely employed for toxicity and viability, we strongly believe that cytotoxicity potential of naproxen 

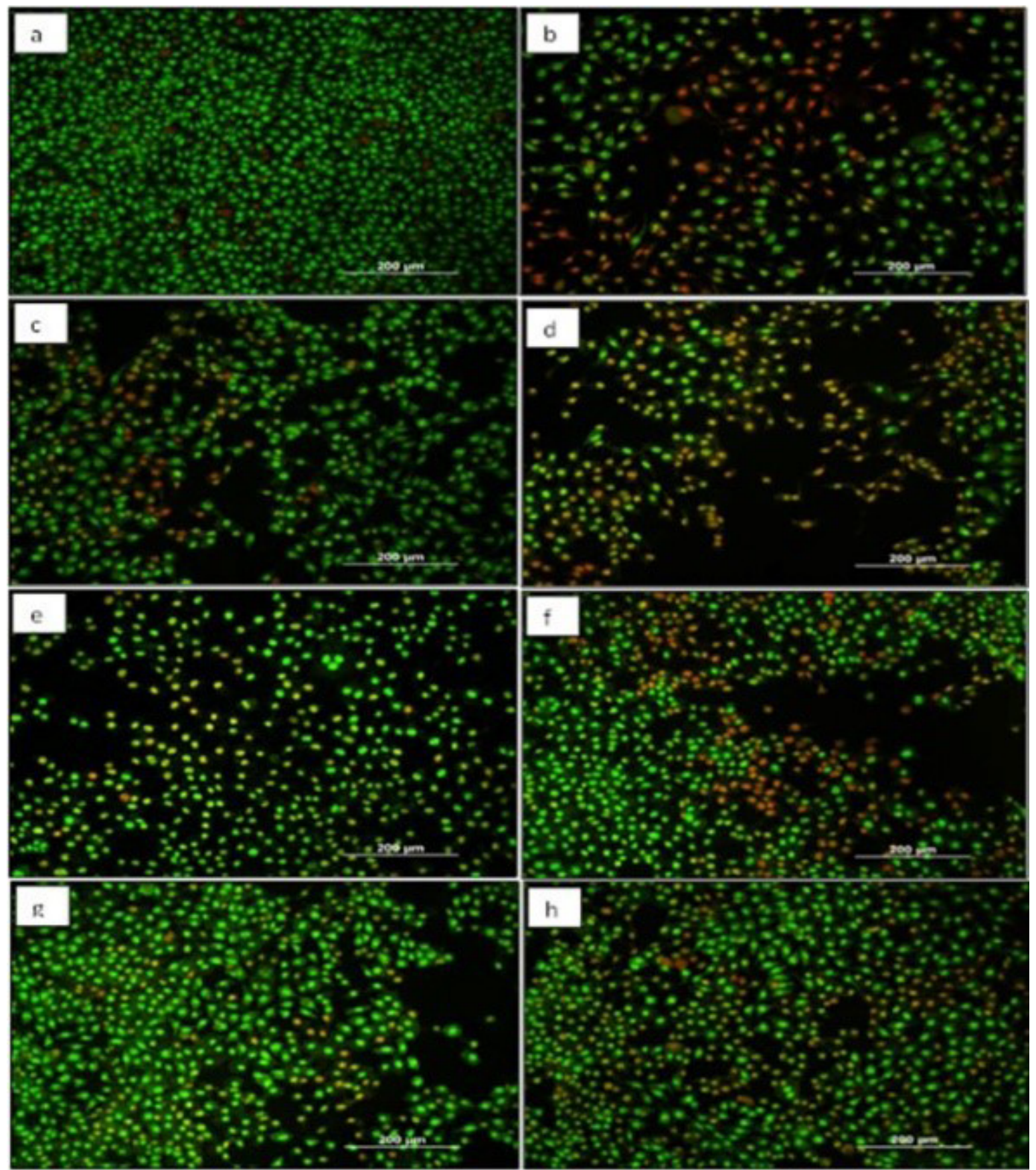

Figure 5. Immunofluorescence staining results of L929 cell line (a) control group and (b-h) gradually decreasing concentrations of O-desmethylnaproxen applied to cells for 24-h. With gradually increased concentration, the number of apoptotic (orange) and necrotic cells (red) increased. Moreover, the proliferation rate was sharply decreased. Original magnifications: 200x (a-h). 


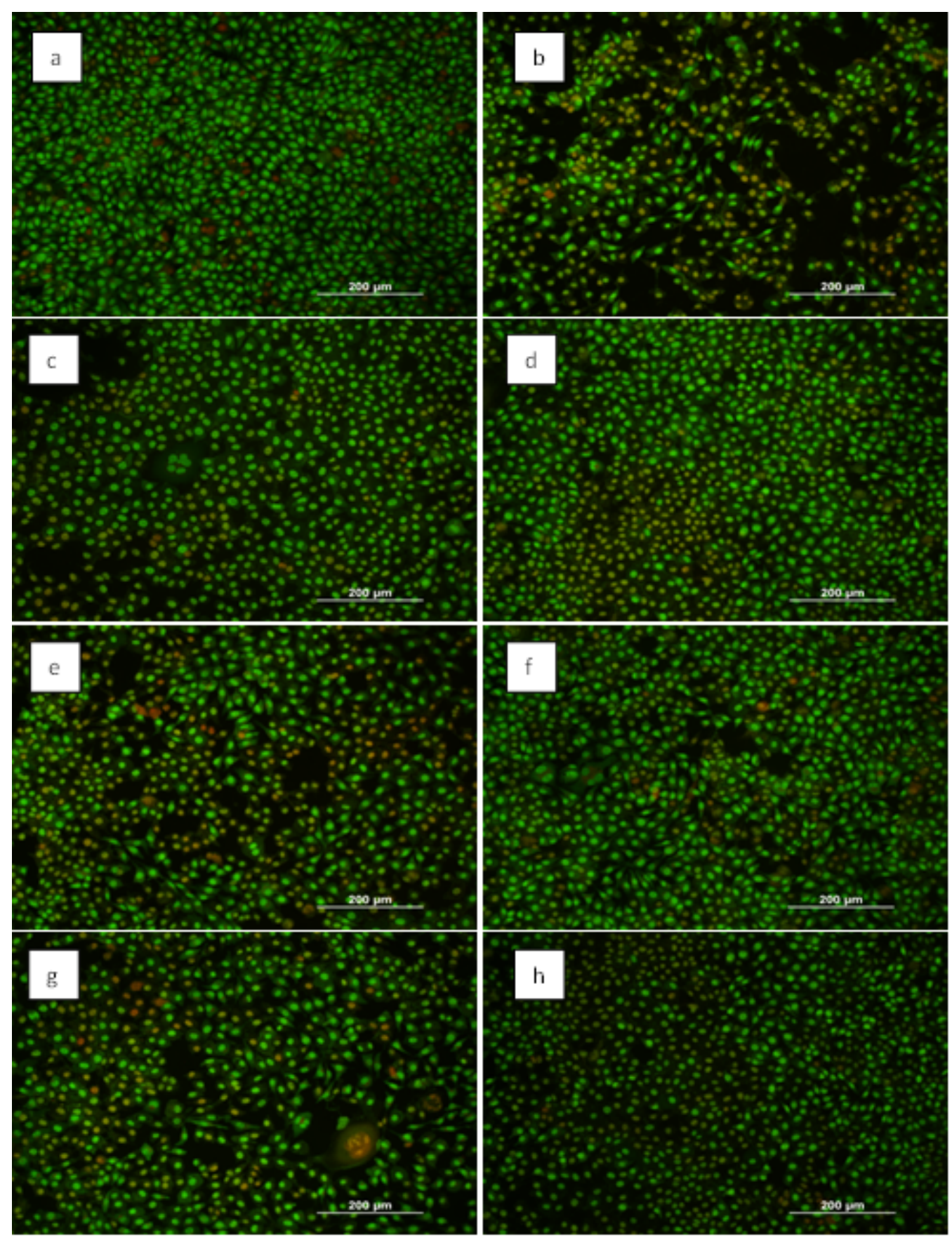

Figure 6. Immunofluorescence staining results of $L 929$ cell line (a) control group and (b-h) gradually decreasing concentrations of naproxen applied to cells for 24 -h. In contrast to all other concentrations, a few apoptotic cells (orange) were observed at a concentration of d1: $0.7 \mu \mathrm{g} / \mathrm{ml}$ (b). Original magnifications: 200x (a-h). 


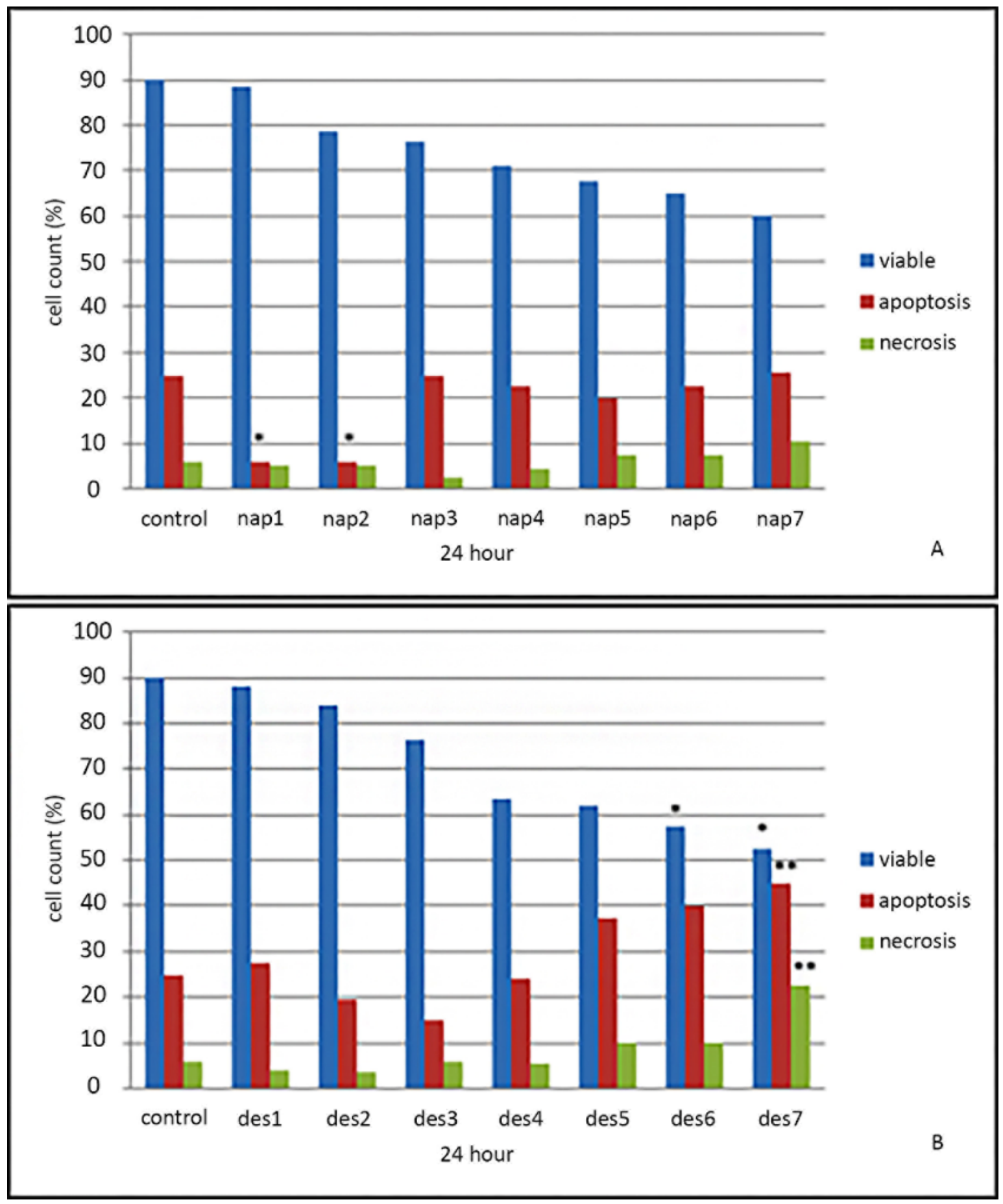

Figure 7. The population of viable, apoptotic (early and late), and necrotic cells in L929 cells treated with naproxen (A) and O-desmethylnaproxen (B) with different doses for 24-h. Results are shown as mean \pm SD mean, derived from at least three replicates $\left({ }^{*} p<0.05\right.$ and $\left.{ }^{* *} p<0.01\right)$. All comparisons were made with respect to the control group. 
and $O$-desmethylnaproxen should also be documented in different mammalian cell line, especially hepatic and renal cell lines.

\section{CONCLUSION}

Our findings demonstrate that naproxen has no toxic effects, contrary to expectations cell viability increase with all doses of this drug. A high dose of $O$-desmethylnaproxen has toxic effects in terms of increase cell death. Non-clinical, laboratory based works always are unqualified for answering clinical questions but, since naproxen is used widely, the results may be handy for further clinical research.

\section{Acknowledgement: None}

\section{References}

1. M. DellaGreca, M. Brigante, M. Isidori, A. Nardelli, L. Previtera, M. Rubino, F. Temussi, Phototransformation and ecotoxicity of the drug Naproxen-Na, Environ. Chem. Lett., 1 (2003) 237-241.

2. R. Runkel, M. Chaplin, G. Boost, E. Segre, E. Forchielli, Absorption, distribution, metabolism, and excretion of naproxen in various laboratory animals and human subjects, J. Pharm. Sci., 61 (1972) 703-708.

3. J.V. Andersen, S.H. Hansen, Simultaneous quantitative determination of naproxen, its metabolite 6-Odesmethylnaproxen and their five conjugates in plasma and urine samples by highperformance liquid chromatography on dynamically modified silica, J. Chromatogr., 10 (1992) 325-33.

4. J.O. Miners, S. Coulter, R.H. Tukey, M.E. Veronese, D.J. Birkett, Cytochromes P450, 1A2, and 2C9 are responsible for the human hepatic O-demethylation of R-and S-naproxen, Biomed. PharmacothEr., 51 (1996) 1003-1008.

5. D.F. Zhong, L. Sun, L. Liu, H.H. Huang, Microbial transformation of naproxen by Cunninghamella species, Acta Pharmacol. Sin., 24 (2003) 442-447.

6. N.M. Davies, K.E. Anderson, Clinical pharmacokinetics of naproxen, Clin. Pharmacokinet., 32 (1997) 268-293.

7. T. Tracy, C. Marra, S. Wrighton, F. Gonzalez, K. Korzekwa, Involvement of multiple cytochrome P450 isoforms in naproxen O-demethylation, Eur. J. Clin. Pharmacol., 52 (1997) 293-298.

8. K. Fent, A. A. Weston, D. Caminada, Erratum to "Ecotoxicology of human pharmaceuticals" [Aquatic Toxicology 76 (2006) 122-159], Aquat. Toxicol., 78 (2006a) 207

9. D. Domaradzka, U. Guzik, D. Wojcieszyńska, Biodegradation and biotransformation of polycyclic non-steroidal antiinflammatory drugs, Rev. Environ. Sci. Biotechnol., 14 (2015) 229-239.

10. H. Hühnerfuss, S. Selke, M. Scheurell, M.R. Shah, S. Nadeem, The drug naproxen and its transformation products as an example for emerging environmental pollutants, Organohalog. Compd., 72 (2010) 467-470.
11. L.D. Buckberry, Cytotoxicity Testing Using Cell Lines, Animal Cell Biotechnology, Humana Press, Totowa, NJ, 1999.

12. M. Isidori, M. Lavorgna, A. Nardelli, A. Parrella, L. Previtera, M. Rubino, Ecotoxicity of naproxen and its phototransformation products, Sci. Total. Environ., 348 (2005) 93-101.

13. F.A. Alherz, D.A. Almarghalani, N.A. Hussein, K. Kurogi, M.C. Liu, A reappraisal of the 6-O-desmethylnaproxen-sulfating activity of the human cytosolic sulfotransferases, Can. J. Physiol. Pharmacol., 95 (2017) 647-651.

14. Y. D. Aracagök, H. Göker, N. Cihangir, Biodegradation of micropollutant naproxen with a selected fungal strain and identification of metabolites. Zeitschrift für Naturforschung C, 72 (2017) 173-179.

15. I. Correia, R. Arantes-Rodrigues, R. Pinto-Leite, I. Gaivão, Effects of naproxen on cell proliferation and genotoxicity in MG-63 osteosarcoma cell line, J. Toxicol. Env. Heal. A, 77 (2014) 916-923.

16. B.I. Cohen, M.K. Pagnillo, B.L. Musikant, A.S. Deutsch, An in vitro study of the cytotoxicity of two root canal sealers, J. Endod., 26 (2000) 228-229.

17. M. Akyol, Z. Akın Polat, S. Özçelik, Ö. Kaya, The effects of strontium chloride on viability of mouse connective tissue fibroblast cells, C.M.J., 35 (2013) 33-38.

18. J. Carmichael, W.G. DeGraff, A.F. Gazdar, J.D. Minna, J.B. Mitchell, Evaluation of a tetrazolium-based semiautomated colorimetric assay: assessment of chemosensitivity testing, Cancer Res., 47 (1987) 936-942.

19. S. Mohan, A. Bustamam, S. Ibrahim, A.S. Al-Zubairi, M. Aspollah, R. Abdullah, M.M. Elhassan, In vitro ultramorphological assessment of apoptosis on CEMss induced by linoleic acid-rich fraction from Typhonium flagelliforme tuber, Evid. Based Complement. Alternat. Med., (2011) 2011.

20. A. Wahab, S. Ibrahim, A.B. Abdul, A.S. Alzubairi, M. Mohamed Elhassan, S.Mohan, In vitro ultramorphological assessment of apoptosis induced by zerumbone on (HeLa), BioMed. Res. Int., (2009) 2009.

21. G. Tan, M. Kaya, A. Tevlek, I. Sargin, T. Baran, Antitumor activity of chitosan from mayfly with comparison to commercially available low, medium and high molecular weight chitosans, In Vitro Cell. Dev. Biol. Anim., 54 (2018) 366-374.

22. E. Marco-Urrea, M. Pérez-Trujillo, P. Blánquez, T. Vicent, G.Caminal, Biodegradation of the analgesic naproxen by Trametes versicolor and identification of intermediates using HPLC-DAD-MS and NMR, Bioresour. Technol., 101 (2010) 2159-2166.

23. E. Ricciotti, G.A. FitzGerald, Prostaglandins and inflammation, Arterioscler. Thromb. Vasc. Biol., 31 (2011) 986-1000.

24. C.E. Smith, S. Soti, T.A. Jones, A. Nakagawa, D. Xue, H. Yin, Non-steroidal anti-inflammatory drugs are caspase inhibitors, Cell Chem. Biol., 24 (2017) 281-292.

25. K. Fent, A.A. Weston, D. Caminada, Ecotoxicology of human pharmaceuticals, Aquat. Toxicol., 76 (2006b) 122-159.

26. C. Carlsson, A.K. Johansson, G. Alvan, K. Bergman, T. Kühler, Are pharmaceuticals potent environmental pollutants?: Part I: Environmental risk assessments of selected active pharmaceutical ingredients, Sci. Total Environ., 364 (2006) 67-87.

27. S. Selke, M. Scheurell, M.R. Shah, H. Hühnerfuss, Identification and enantioselective gas chromatographic mass-spectrometric separation of $O$-desmethylnaproxen, the main metabolite of the drug naproxen, as a new environmental contaminant, J. Chromatogr. A., 1217 (2010) 419-423. 
28. G. Lucena,C. Reyes-Botella, O. García-Martínez, J. Ramos Torrecillas, E.D.L., Bertos, C. Ruiz, Effect of NSAIDs on the aminopeptidase activity of cultured human osteoblasts, Mol. Cell. Endocrinol., 426 (2016) 146-154.

29. E. De Luna-Bertos, J. Ramos-Torrecillas, O. García-Martínez, A. Guildford, M. Santin, C. Ruiz, Therapeutic doses of nonsteroidal anti-inflammatory drugs inhibit osteosarcoma MG-63 osteoblast-like cells maturation, viability, and biomineralization potential, Sci. World J., (2013) 2013.

30. H. Axelsson, C. Lönnroth, M. Andersson, K. Lundholm, Mechanisms behind COX-1 and COX-2 inhibition of tumor growth in vivo, Int. J. Oncol., 37 (2010) 1143.

31. L. Díaz-Rodríguez, O. García-Martínez, M. Arroyo-Morales, C. Reyes-Botella, C. Ruiz, Antigenic Phenotype and Phagocytic Capacity of MG-63 Osteosarcoma Line, Ann. N. Y. Acad. Sci., 1173 (2009) E46-E54.
32. L. Díaz-Rodríguez, O. García-Martínez, E. De Luna-Bertos, J. Ramos-Torrecillas, C. Ruiz, Effect of ibuprofen on proliferation, differentiation, antigenic expression, and phagocytic capacity of osteoblasts, J. Bone Miner. Metab., 30 (2012a) 554-560.

33. L. Díaz-Rodríguez, O. García-Martínez, M.A. Morales, L. Rodríguez-Pérez, B. Rubio-Ruiz, C. Ruiz, Effects of indomethacin, nimesulide, and diclofenac on human MG-63 osteosarcoma cell line, Biol. Res. Nurs., 14 (2012b) 98-107.

34. E. De Luna-Bertos, J. Ramos-Torrecillas, O. García-Martínez, L. Diaz-Rodriguez, C. Ruiz, Effect of aspirin on cell growth of human MG-63 osteosarcoma line, Sci. World J., (2012) 2012.

35. A. Aresta, T. Carbonara, F. Palmisano, C.G.Zambonin, Profiling urinary metabolites of naproxen by liquid chromatographyelectrospray mass spectrometry, J. Pharm. Biomed. Anal., 41 (2006) 1312-1316. 